\title{
Psikoedukasi Mengasuh Dengan Empati Untuk Meningkatkan Kualitas Parenting Pada Kader Posyandu Di Desa Dukuh, Boyolali
}

\author{
Sheilla Varadhila Peristianto \\ Universitas Mercu Buana Yogyakarta \\ sheillavaradhila@gmail.com
}

\begin{abstract}
Parents in carrying out their role as caregivers show various forms of parenting. Parents feel paid attention in many events, but children do not behave in accordance with the expectations of the elderl. In Desa Dukuh, Banyudono, Boyolali, the majority of parents every day work so that for children there is rarely a given quality time. In Desa Dukuh, Banyudono, Boyolali, the majority of parents work every day, so there is rarely quality time given for the child. The child thinks that parents are busy working and often get angry to them, while parents feel they donot appreciate parent's hard work to meet the needs of the family.

The subject in this study was Posyandu cadres in Desa Dukuh which a total of 25 people, hopefully the subject can continue information to parents in the neighborhood. Researchers had conducted the assessment with the methods of interviews, observations, FGI (Focused Group Interview) and document analysis. The material used in psychoeducation was transited from the techniques of building empathy (Bailey, Perkins \& Wilkins, 1995). Psychoeducation was given for three sessions conducted in one meeting, as for pre-test measurements in Session 1, post-Test at session 3, and follow up done 1 week later.

Based on the analysis using the paired sample T-Test obtained the result $t=-3.745$ with $P=$ 0.001 ( $p<0.001)$. From these results it can be known that psychoeducation builds empathy to improve understanding of parenting to children, and parents understand the initial way to know the child's condition. Psychoeducation builds empathy for the elderly to improve the quality of parenting to the child.

Keywords : cadre, parenting, empathy, parenting
\end{abstract}

\begin{abstract}
Abstrak
Orang tua dalam menjalankan perannya sebagai pengasuh menampilkan bentuk pengasuhan yang beragam. Banyak kejadian, orang tua merasa memberikan perhatian, namun anak tidak berperilaku sesuai dengan harapan orang tua. Di Desa Dukuh, Banyudono, Boyolali, mayoritas orang tua setiap hari bekerja sehingga bagi anak jarang ada waktu berkualitas yang diberikan. Anak berfikir bahwa orang tua sibuk bekerja dan tak jarang mendapat amarah dengan nada tinggi, sedangkan orang tua merasa anak tidak menghargai kerja keras demi memenuhi kebutuhan keluarga.

Subjek dalam penelitian ini adalah kader posyandu di Desa Dukuh yang berjumlah 25 orang, diharapkan subjek dapat melanjutkan informasi kepada orang tua di lingkungan sekitar. Peneliti melakukan asesmen dengan metode wawancara, observasi, FGI (Focused Group Interview) dan analisis dokumen. Materi yang digunakan pada psikoedukasi ditranslasi dari tehnik membangun empati (Bailey, Perkins \& Wilkins, 1995). Psikoedukasi diberikan selama tiga sesi yang dilaksanakan dalam satu kali pertemuan, adapun pengukuran pre-test pada sesi 1 , post-test pada sesi 3, dan follow up dilakukan 1 minggu kemudian.

Berdasarkan analisis menggunakan paired sample $t$-test didapatkan hasil $t=-3,745$ dengan $p=0,001(p<0,001)$. Dari hasil tersebut dapat diketahui bahwa psikoedukasi membangun empati meningkatkan pemahaman tentang pengasuhan kepada anak, dan orang tua memahami cara awal untuk mengetahui kondisi anak. Psikoedukasi membangun empati pada orang tua meningkatkan kualitas dalam melakukan pengasuhan kepada anak.
\end{abstract}

Kata Kunci : kader, pengasuhan, empati, parenting 


\section{Pendahuluan}

Keluarga adalah lingkungan yang sangat berpengaruh bagi perjalanan hidup seseorang. Oleh sebab itu keluarga memiliki peran besar memenuhi kebutuhan hidup setiap anggotanya, baik kebutuhan makan minum, tempat tinggal, pakaian serta kebutuhan akan kasih sayang. Dalam keluarga terdapat figur yang sangat berperan penting yaitu orang tua.

Peran orang tua dalam kehidupan keluarga begitu kompleks, yaitu mulai dari mencari nafkah, memberikan perlindungan, pengawasan dan pengasuhan, serta berperan dalam lingkungan sosial. Salah satu peran yang sangat penting adalah mengasuh anak, tujuannya adalah supaya anak berkembang dan memiliki pribadi yang baik. Dengan pengasuhan yang baik seorang anak akan mampu melalui semua tugas perkembangan di setiap fasenya (Jauziyyah, 2010).

Pengasuhan ini dapat diartikan sebagai pola interaksi antara anak dengan orang tua meliputi berbagai aspek yaitu fisik dan non-fisik. Aspek fisik diantaranya adalah kebutuhan seperti makanan, minuman, dll, sedangkan aspek non-fisik diantaranya seperti perhatian, kasih sayang, empati, dan sebagainya.

Kasih sayang, cinta kasih, dan empati atau sikap yang penuh dengan perhatian dari orang tua dalam mengasuh merupakan teladan yang baik kepada setiap anak karena akan membentuk sikap anak kelak yang selalu didasari dengan rasa sayang, cinta, dan penuh perhatian atau peduli terhadap lingkungan. Namun selain itu juga terdapat orang tua yang kurang menunjukkan kasih sayang dan kepedulian atau perhatian pada anaknya (Widyawati dan Kurniawan, 2008).

Orang tua yang kurang memberikan perhatian pada anak bisa disebabkan oleh beberapa faktor diantaranya adalah pendidikan dan ekonomi (Widyawati dan Kurniawan, 2008). Keluarga dengan taraf ekonomi dan pendidikan yang rendah rentan terhadap kurangnya pengasuhan orang tua pada anak, orang tua dituntut bekerja lebih keras demi memenuhi kebutuhan keluarga, sedangkan anak kurang mendapatkanperhatian dan waktu yang berkualitas dalam keluarga.

Desa Dukuh, Kecamatan Banyudono, Boyolali, mayoritas penduduknya bekerja sebagai buruh pabrik serta memiliki pendidikan rendah. Total penduduk di desa tersebut kurang lebih 1400 jiwa, dengan 599 jiwa tamat SD, 201 jiwa tidak tamat SD dan sisanya adalah tamatan SMP, SMA serta Perguruan Tinggi. Setiap harinya orang tua bekerja dengan sistem sift, shift siang mulai pukul 07:30 - 17:00, sedangkan sift malam mulai pukul 19.30 - 05.00. Apabila orang tua bekerja pada malam hari maka pada siang harinya ia beristirahat dan pada sore harinya orang tua berangkat bekerja, begitu juga sebaliknya.

Di Desa Dukuh Banyudono Boyolali, anak merasakan rumah bukanlah tempat yang menyenangkan apabila berlama-lama di dalamnya. Sepulang sekolah anak ingin menceritakan 
keluh kesahnya, namun terkadang anak tidak menemui orang tuanya di rumah. Menurut penuturan salah satu siswa SMP di Banyudono, ia kehilangan uangnya di jalan setelah pulang sekolah, iapun justru dimarahi oleh orang tuanya setibanya di rumah. Dalam peristiwa tersebut anak merasa sedih karena kehilangan uang, yang ia butuhkan adalah ketenangan dengan pulang ke rumah mengadu kepada orang tua, namun karena orang tua yang sudah lelah dengan urusan pekerjaan maka perisitiwa yang dialami oleh anak tersebut cenderung diterima sebagai hal yang negatif yaitu kecerobohan anaknya sendiri.

Selain itu di sekitar Desa Dukuh Kecamatan Banyudono Boyolali adalah salah satu daerah di Boyolali yang memiliki faktor resiko tinggi terjangkit HIV. Menurut data dari KPA Boyolali terdapat 13 penderita HIV di Banyudono Boyolali serta rentan menjadi tempat persebaran HIV karena terdapat umbul yang digunakan untuk sesirih, panti pijat, dan hotel kelas mawar dengan biaya yang murah. Pada awalnya umbul tersebut digunakan untuk ritual sesirih, yaitu proses ritual semedi dengan cara berendam tanpa menggunakan busana, baik laki-laki ataupun perempuan berendam pada umbul yang sama. Menurut pengurus desa setempat hal tersebut semakin lama membuat pihak yang melakukan sesirih menjadi tergoda untuk melakukan hubungan seksual. Sejak tahun 2009, setiap malam mulai pukul 20.00 WIB sampai dengan 01.00 kemudian dilanjutkan sampai pukul 03.00 WIB terdapat kurang lebih 10 sampai dengan 20 PSK yang datang ke tempat-tempat sesirih tersebut untuk menjajakan diri. Penduduk sekitar kadang-kadang menemui pasangan laki-laki dengan perempuan sedang melakukan hubungan seks di sekitar umbul tempat sesirih tersebut. Penuturan Kepala Desa umbul juga digunakan sebagai tempat pertemuan antara pelaku sesirih dengan PSK selanjutnya mengajaknya menginap di salah satu hotel kelas mawar yang berjarak $2 \mathrm{~km}$ dari Desa Dukuh.

Peristiwa tersebut tentunya meresahkan masyarakat, kususnya orang tua yang memiliki anak dengan usia remaja, karena dikhawatirkan peristiwa tersebut memberi contoh negatif kepada remaja. Ditambah dengan orang tua yang bekerja lembur di pabrik sehingga kurang mengetahui aktivitas anak dalam bergaul.

Adanya fenomena tersebut membuat orang tua yang sadar akan tugasnya khawatir apabila anak mereka masuk pada pergaulan yang salah, namun karena kesibukan dalam mencari nafkah membuat orang tua bingung antara mendahulukan anak atau pekerjaannya. Maka dari itu perlu ada nya psikoedukasi untuk membangun empati dalam meningkatkan kualitas hubungan antara orang tua kepada anaknya. Psikoedukasi membangun empati ini diharapkan sebagai pengetahuan awal untuk menciptakan kualitas pengasuhan yang baik bagi orang tua kepada anaknya.

Berdasarkan paparan data pada latar belakang, maka masalah yang dapat diidentifikasi yaitu : 
1. Kesibukan orang tua di Desa Dukuh sebagai buruh pabrik sehingga kurang dapat melakukan pengawasan pada aktifitasnya di luar rumah.

2. Kurangnya pemahaman orang tua akan pengasuhan yang baik pada anak.

Seseorang yang memiliki pengetahuan sangat terbatas mengenai sesuatu (dalam hal ini mengenai parenting), maka orang tersebut cenderung kurang mampu dalam melakukan suatu hal dengan baik dan benar, sehingga hasil yang diberikan kurang sesuai (Widiyawati \& Kurniawan, 2008). Maka dari itu, perlu suatu usaha untuk menambah pengetahuan atau memperluas wawasan megenai pengasuhan tersebut. Pemahaman mengenai Parenting Skill merupakan salah satu cara yang cukup efektif untuk memperkaya bekal pengetahuan mengenai keterampilan-keterampilanyang harus diketahui orangtua dalam mengasuh anak. Program parenting skill pada umumnya adalah prinsip-prinsip social-learning dengan pemahaman bahwa perilaku-perilaku yang dikuatkan akan terjadi lebih sering (Kazdin, dalam Widiyawati \& Kurniawan, 2008). Orangtua yang mengikuti pelatihan dilaporkan memiliki perilaku yang positif terhadap anak (Widiyawati \& Kurniawan, 2008).

Pelatihan Parenting Skill adalah sebuah tindakan atau usaha untuk menambah pengetahuan, memperluas wawasan, serta meningkatkan keterampilan pengasuhan yang dimiliki. Pelatihan ini didesain untuk mengisi gap pendidikan dengan memberikan keterampilan dasar dalam format pembelajaran yang sesuai untuk semua tingkatan. Selain itu juga untuk menyediakan pendidikan dengan pedoman keterampilan yang lengkap bagi orangtua dan penguasaan filosofi yang digunakan dalam pelatihan tersebut (dalam Bailey, Perkins, \& Wilkins, 1995).

Hal tersebut akan meningkatkan pemahaman orang tua bagaimana mengasuh anak dengan baik dan benar sehingga hasil yang diharapkan dapat tercapai.Sesuai dengan faktor pergaulan bebas yang mengarah pada perilaku seks bebas menurut Warianto yaitu orang tua. Maka dari itu perilaku remaja sulit diubah tanpa peran dari orang tua, sehingga orang tua harus berpartisipasi penuh untuk memberikan perhatian kepada anak. Dengan pemahaman yang tepat, orang tua akan berhasil dalam berhubungan dengan masalah-masalah kenakalan yang kronis (Banks,dkk.,1991).

Feldman \& Werner (dalam Garliah \& Nasution, 2002) menambahkan bahwa pelatihan orangtua ini juga tidak hanya berdampak secara positif pada efektivitas orangtua dalam mengurangi masalah perilaku anak, tetapi juga dalam pencegahan peristiwa yang baru serta mengajarkan pada anak mengenai perilaku yang tepat (Widiyawati \& Kurniawan, 2008).

Pergaulan bebas itu sendiri disebabkan karena kurangnya peran orang tua dalam membimbing anaknya yang berusia remaja. Remaja yang memiliki banyak aktivitas dan kewajiban seperti menuntut ilmu di sekolah sering mengalami permasalahan baik di lingkungan sekolah ataupun di lingkungan rumah, hal tersebut membuat remaja membutuhkan tempat 
untuk mengekspresikan emosi, memperoleh penghargaan atas usahanya serta perlindungan (Maulina \& Sutatminingsih, 2005). Namun sikap orang tua yang cenderung kurang memperhatikan membuat remaja mencari perhatian dan penghargaan di luar rumah. Orang tua menganggap kewajiban anak adalah sekolah dan merasa sudah memberikan perhatian apabila mampu mencukupi kebutuhan anaknya baik di rumah maupun di sekolah Sulistyaningsih (2005).

Sikap orang tua tersebut dikarenakan kurangnya kemampuan berempati kepada anaknya yang berusia remaja, didukung dengan faktor ekonomi yang cenderung rendah menyebabkan orang tua harus menyediakan banyak waktu untuk bekerja dalam rangka memenuhi kebutuhan sehari-hari sehingga tidak lagi mepedulikan kualitas pengasuhan terhadap anak. Rendahnya pendidikan juga ditengarai menjadi faktor rendahnya kesadaran orangtua untuk mengembangkan keterampilan anak maupun keterampilan orangtua dalam mengasuh anak itu sendiri (Widiyawati \& Kurniawan, 2008). Dengan adanya pemahaman berkaitan dengan Keterampilan Pengasuhan (pareting skill) diharapkan agar orang tua mampu menumbuhkan komunikasi yang berkualitas di dalam rumah sehingga remaja tidak akan mencari kenyamanan di luar, karena sudah mendapatkan di dalam keluarga, sehingga mampu mencegah remaja untuk melakukan hal-hal yang mengarah pada pergaulan bebas bahkan terhindar dari bahaya terinfeksi HIV/AIDS.

\section{Metode Penelitian}

Berdasarkan permasalahan yang ada, maka dari itu diperlukan rancangan pengumpulan data sebagai berikut :

Tabel 1. Rancangan Pengumpulan Data

\begin{tabular}{|c|c|c|}
\hline No & $\begin{array}{l}\text { Teknik } \\
\text { Pengumpulan } \\
\text { Data }\end{array}$ & Tujuan \\
\hline 1 & $\begin{array}{l}\text { Wawancara awal } \\
\text { semi terstruktur }\end{array}$ & $\begin{array}{l}\text { Untuk memperoleh gambaran yang utuh dan } \\
\text { mendalam mengenai kualitas pengasuhan (parenting) }\end{array}$ \\
\hline 2 & $\begin{array}{l}\text { Wawancara } \\
\text { (FGI) }\end{array}$ & $\begin{array}{l}\text { Untuk mengetahui : } \\
\text { 1. Permasalahan yang berkaitan dengan dampak } \\
\text { kurangnya kualitas parenting } \\
\text { 2. Mengetahui alternative solusi dari masyarakat } \\
\text { setempat } \\
\text { 3. } \\
\text { Merancang intervensi yang tepat }\end{array}$ \\
\hline 3 & $\begin{array}{l}\text { Analisis } \\
\text { dokumen }\end{array}$ & $\begin{array}{l}\text { Untuk mengetahui data-data kuantitatif berkaitan } \\
\text { dengan pekerjaan dan pendidikan orang tua di Desa } \\
\text { Dukuh }\end{array}$ \\
\hline
\end{tabular}

\section{Hasil Penelitian}


Pelaksanaan psikoedukasi dilakukan pada hari Kamis, 22 Oktober 2017 di Balai Kantor Kelurahan Desa Dukuh, Kecamatan Banyudono. Psikoedukasi dilaksanakan dalam tiga tahap, yang pertama adalah pemahaman mengenai pergaulan bebas remaja, kemudian memperkenalkan respecting feelings beserta role play dengan langkah sebagai berikut; Memperhatikan dan mendengarkan anak, Menggambarkan perasaan anak dalam kata-kata, Memposisikan orang tua pada posisi anak, kemudian apa perasaan yang dirasakan oleh anak, Menanyakan (kroscek) kepada anak tentang apa emosi anak yang ada di dalam fikiran orang tua, dan Kemudian dilanjutkan dengan sesi terakhir yaitu menyampaikan kesimpulan diikuti dengan penutupan.

Berdasarkan skor pre dan post-test psikoedukasi, maka didapatkan hasil bahwa terdapat 12 peserta $(63,2 \%)$ mengalami peningkatan pemahaman, 6 peserta $(31,6 \%)$ pemahamannya tetap (tidak bertambah ataupun kurang), dan 1 orang $(5,3 \%)$ mengalami penurunan skor. Intervensi juga dinilai efektif ditunjukkan dengan analisis paired sample t-test bahwa terdapat perbedaan yang signifikan antara pemahaman mengenai membangun empati untuk orang tua sebelum dan sesudah diberikan psikoedukasi. Setelah psikoedukasi berakhir, orang tua menyadari bahwa selama ini anaknya yang berusia remaja lebih memilih untuk segera pergi dari rumah ataupun tiduran di kamar sepulang subjek bekerja. Orang tua mengetahui bahwa kurangnya empati yang membuat anak dengan orang tua seakan terdapat jarak.Orang tua juga mengetahui perilaku apa saja yang termasuk dalam pergaulan bebas, serta mampu mempraktekkan bagaimana berempati kepada anak ataupun orang lain.

\section{Diskusi}

Adanya kawasan wisata di Desa Dukuh membawa dampak positif dan negatif bagi masyarakat setempat. Dampak positifinya kawasan wisata tersebut dapat membuka lapangan pekerjaan baru bagi masyarakat, seperti membuka warung kelontong, warung makan, serta pemasukan masyarakat melalui parkir, serta membuat Desa Dukuh di kenal oleh masyarakat luas. Namun dampak positif tersebut kurang seimbang jika dibandingkan dengan dampak negatif yang lebih berbahaya. Umbul Pengging yang merupakan kawasan wisata digunakan untuk ritual bertapa dan tempat untuk menenangkan pikiran. Namun disekitar kawasan Pengging terdapat perhotelan dan panti pijat, sehingga banyak warga penduduk asli maupun pendatang yang keluar masuk kawasan tersebut yang sebenarnya berniat untuk mengunjungi hotel atau panti pijat untuk melakukan perselingkuhan dan seks bebas.

Di Desa Dukuh terdapat beberapa tempat ritual atau masyarakat setempat sering menyebut dengan sesirih. Hal tersebut diduga menjadi penyebab utama penyebaran HIV di Desa Dukuh selain adanya hotel dan panti pijat, karena hampir setiap malam banyak PSK dari luar daerah ataupun penduduk asli menjajakan diri di sekitar tempat sesirih dan pelanggannya 
adalah dari berbagai usia mulai remaja sampai dewasa bak dari dalam ataupun luar Desa Dukuh.

Dampak dari adanya lokasi sesirih di Desa Dukuh adalah angka perceraian akibat perselingkuhan menjadi tinggi yaitu sebesar 60\% meskipun yang sudah terdata di Kantor Kelurahan hanya kurang lebih 20 \%. Selain itu terdapat kelompok remaja di Desa Dukuh cenderung mengikuti pergaulan bebas yaitu sering begadang melakukan hal yang kurang bermanfaat, minum-minuman keras dan mungkin juga ada yang terjun ikut mengunjungi hotel dan panti pijat di kawasan Desa Dukuh. Hal tersebut dikarenakan orang tua yang kurang memberikan pengasuhan serta pengawasan dengan baik, profesi orang tua mayoritas adalah sebagai buruh pabrik dengan kesibukan yang tinggi. Orang tua yang piket kerja malam menghabiskan waktu siangnya untuk beristirahat, seringkali karena kondisi fisik yang kurang fit membuat orang tua mudah kesal dengan perilaku anak sehingga sering terdengar orang tua yang memarahi anak dan terdengar oleh tetangga. Ketika orang tua tidak ada di rumah beberapa kelompok remaja sering berkumpul di suatu lokasi hanya sekedar nongkrong dan bercanda dengan teman-temannya, namun juga sering ditemui remaja yang mengkonsumsi alkohol bersama-sama. Selain itu terdapat contoh yang kurang baik untuk remaja di Desa Dukuh, di mana setiap malam terdapat PSK yang menawarkan jasa di sekitar umbul, berdekatan dengan lokasi kumpul remaja tersebut. Karena jumlah remaja yang terdapat di Desa Dukuh tergolong banyak, dan tingkat pendidika yang cenderung rendah membuat mereka rentan terpengaruh hal tersebut, serta didukung dengan perhatian yang kurang dari orang tua membuat remaja semakin beresiko untuk mengikuti perilaku yang mengarah pada pergauan bebas tersebut.

Menurut warga Desa Dukuh hal tersebut harus dicegah bagaimanapun caranya, karena perilaku remaja tersebut memberikan contoh yang sangat buruk terhadap anak-anak di bawah umur di Desa Dukuh serta dapat menjadi gerbang penyebaran HIV/AIDS, maka dari itu masyarakat Desa Dukuh mengusulkan supaya diadakan penyuluhan kepada orang tua bagaimana mengasuh anak supaya tidak masuk dalam pergaulan bebas yang pada akhirnya dapat membentengi generasi kehidupan di Desa Dukuh dari bahaya HIV/AIDS.

Berdasarkan kasus yang terdapat di Desa Dukuh, maka praktikan memberikan intervensi berupa "Psikoedukasi Parenting Skill Dengan Tehnik "Respecting Feelings" (Membangun Empati) Pada Orang Tua Untuk Membentengi Remaja Dari Pergaulan Bebas". Intervensi diberikan kepada Kader PKK dan Posyandu Desa Dukuh dengan harapan dapat memberikan informasi kepada seluruh orang tua di dukuh masing-masing sehingga informasi dapat tersebar luas kepada seluruh orang tua. Tujuan dalam intervensi ini adalah untuk memberikan pemahaman kepada orang tua dalam mencegah pergaulan bebas remaja yang beresiko terinfeksi HIV/AIDS, serta memahami langkah-langkah membangun empati supaya tercipta 
komunikasi yang efektif antara orang tua dengan anak. Praktikan memilih orang tua sebagai subjeknya karena menurut Banks beserta timnya (1991) berasumsi bahwa tanpa disengaja orangtua menciptakan kondisi yang mendorong ke arah masalah perilaku anak, oleh karena itu perilaku anak tidak dapat diubah tanpa keterlibatan dan partisipasi orangtua (Widyawati dan Kurniawan, 2008).

Menurut Devito (Afrilia dan Kuniarti, 2008) empati merupakan salah satu aspek dari komunikasi efektif orang tua dengan anak, empati yang dimaksudkan adalah kemampuan untuk merasakan individu lain sebagaimana seperti yang dirasakan pada diri sendiri. Keterampilan Parenting sendiri diharapkan mampu menambah pengetahuan dan berguna untuk mendorong orangtua agar lebih terampil dalam mengasuh anak-anak mereka di kehidupan sehari-hari serta mampu mengatasi kesulitan-kesulitan yang terjadi (Baileys, Perkins, Wilkins, 1995).

\section{Kesimpulan}

Dari hasil penelitian yang telah dilakukan maka dapat diambil kesimpulan bahwa:

1. Permasalahan yang terdapat di desa Dukuh yaitu kurangnya kualitas parenting

2. Penyebab kurangnya kualitas parenting yaitu dikarenakan kurangnya pengetahuan orang tua tentang pentingnya pengasuhan yang baik serta kesibukan orang tua dalam bekerja.

3. Penanganan yang tepat untuk mencegah pergaulan bebas remaja adalah dengan memberikan psikoedukasi kepada perwakilan tokoh masyarakat yaitu seluruh ketua RT dan Kader Posyandu Desa Dukuh berkaitan dengan pergaulan bebas remaja yaitu, psikoedukasi "membangun empati pada orang tua untuk meningkatkan kualitas parenting" Saran

Dari hasil penelitian dan penanganan yang telah dilakukan maka saran yang diberikan adalah; Peserta psikoedukasi telah memiliki pemahaman tentang bagaimana membangun empati pada orang tua kepada anak, diharapkan peserta dapat mempraktekkan dan melanjutkan informasi yang diperoleh kepada masyarakat di RT dan Dusun masing-masing.

Kepala desa dan perangkat desa sebaiknya memberikan anjuran untuk organisasi kepemudaan seperti Karang Taruna atau Forum Komunitas Remaja Masjid (FKRM)supaya aktif dan melakukan kegiatan yang dapat mengurangi pergaulan bebas remaja di Desa Dukuh

\section{Daftar Pustaka}

Bailey, J., Perkins, S., Wilkins, S. (1995). Parenting Skilss. New York: Cornell University. Fuhrmann, B.S. 1990. Adolescence, adolescent. London: Foresman and Company. 
Garliah, L., Nasution, Fatma, K., S. (2005). Peran Pola Asuh Orang Tua Dalam Motivasi Berprestasi. Jurnal Psikologia. (Vol. I. No. 1. Hal. 8-15. ISSN: 18580327).

Hurlock, E. B. (1994). Psikologi Perkembangan, Suatu Pendekatan Sepanjang Rentang Kehidupan. Jakarta: Erlangga.

Maulina, B., Sutatminingsih, R. (2005). Stres Ditinjau dari Harga Diri pada Ibu yang Memiliki Anak Penyandang Retardasi Mental. Jurnal Psikologia. (Vol. I. No. 1. Hal. 31-38. ISSN: 18580327).

Santrock, J, W. (2003). Life Span Development: Perkembangan Masa Hidup (Jilid 2, Edisi 5). Jakarta: Erlangga.

Setianti, Y., Hafiar H., Nugraha., A. R. (2008) Penyuluhan Komunikasi Keluarga Dalam Membina Generasi Muda Di Madrasah Aliyah Mathlaul Ulum Desa Tanjung Kamuning Kecamatan Tarogong Garut. (Tesis, Tidak diterbitkan). Bandung: Universitas Padjajaran, Indonesia.

Utami, Wuri., Aminoto, Cokro., Wahanani, Evi. (2012). Hubungan Tingkat Pengetahuan Tentang Aborsidengan Sikapremaja Putri Terhadap Seks Pranikahdi Kelas Xii Sman Kutowinagun. Jurnal Ilmiah Kesehatan Keperawatan. (Vol. 8. No. 3. 107-112).

Widiyawati, L. Kurniawan I. R. (2008). Pengaruh Pelatihan Parenting Skill Terhadap Parenting Efficacy. (Naskah Publikasi). Yogyakarta: Universitas Islam Indonesia, Indonesia. 